ROCZNIKI TEOLOGICZNE

Tom LXVI, zeszyt 11 - 2019

DOI: http://dx.doi.org/10.18290/rt.2019.66.11-3

FR. FAUSTINUS IK. UGWUANYI

\title{
GOD'S COVENANTS AND THE SACRAMENTS OF CHRISTIAN INITIATION
}

\begin{abstract}
A b s t r a c t. A Catechetical explanation of the Scriptures and their relation to liturgy has become urgent, especially in today's secular society where most of the Church's doctrines and faith-practices are under threat of either losing their meaning or misinterpreted. Also, it has been contended that there is a connection between God's covenants and the New Testament Sacraments of Christian initiation. The article aims to explain the Scriptural relationship of the Sacraments of Christian initiation with God's covenants. The relevance of the study is not only to provide an explanation because of the growing awareness and the constant search for explanations of things but also to reaffirm the importance of these Sacraments and the essential nature of Christ who is God's wisdom and power.
\end{abstract}

Key words: God's covenants; the Sacraments of Christian initiation; Christ-God's wisdom and power.

It was interesting to observe in one of my catechism classes that not many people know much about the historical and theological background of the day to day practices in the society and the Church. Perhaps, the judgment about who to blame would be reserved for another discussion. Nevertheless, in the midst of the growing awareness and the constant search for explanations of things that border around man, which does not exclude faith and religion, it has become necessary to research into the knowledge of some modern ideologies and Church's practices to show their social relevance and theological background. Such explanations will help the individual or the faithful to

Fr. Faustinus IK. UgwuanYi, Doctoral Student - History of Philosophy, Faculty of Philosophy, The John Paul II Catholic University of Lublin; address: ul. Radziszewskiego 7, 20-039 Lublin; e-mail: fadaike@yahoo.com; ORCID ID: 0000-0003-4755-2825. 
realize better and appreciate all the more the objectives of such practices. One of these practices that come to mind is the sacrament of Christian initiation. According to the Catholic teaching, these sacraments of Christian initiation which include Baptism, Confirmation and Holy Eucharist closely combine to bring the faithful to the family of God and Christ's full stature. These sacraments at the same time enable the faithful to carry out their missions as sons and daughters of God both in the Church and in the world. The aim of this article, therefore, is not only to explain the theological background of these sacraments but also to reaffirm their importance and the essential nature of Christ who is God's wisdom and power.

\section{EXPLANATION OF TERMS}

A covenant could be described as an agreement between two parties and also involves promises on the part of the individual parties. The concept of the covenant between God and His people is one of the major themes which run through the Bible. The Essene covenanters, ${ }^{1}$ the people of the Dead Sea Scrolls contributed a lot to the revival of some notions of God's covenant with the Israelites. The early Christian scholars also did much in reviving this concept. ${ }^{2}$ The word "covenant" comes from a Hebrew root berrĩt in the Old Testament meaning "to cut." This Hebrew word berrĩt occurs 287 times in the Old Testament, mainly in the singular. ${ }^{3}$ Its equivalent term diatheke was used in the Septuagint and was later carried over to the New Testament. ${ }^{4}$ This Hebrew meaning explains the various scenes seen in the Old Testament wherein two people pass through the cut bodies of slain animals after making a treaty or covenant. ${ }^{5}$ This was the type of covenant God made with Abraham in Genesis 17:2. Sometimes, a shared meal follows this agreement like in the case of Laban and Jacob in Genesis 31:54. Summarily, this Old Testa-

\footnotetext{
${ }^{1} \mathrm{Cf}$. The Essene covenaters are group of people or a community that entered the new covenant in the land of Damascus and bound themselves to the Law of Moses.

${ }^{2}$ Cf. Delbert R. Hillers, "Covenant," in: The Encyclopedia of Religion, vol. 4, ed. by Mircea Eliade (New York: Macmillan Publishing Company, 1987), 134.

${ }^{3}$ Cf. Lothar PERLitT, "Covenant," in: Erwin FAhlBusch et al. (eds.), The Encyclopedia of Christianity, vol. 1 (Michigan: Wm. B. Eerdmans Publishing Company, 1999), 710.

${ }^{4}$ Cf. M.G. EAston, "Covenant," in Illustrated Bible Dictionary, $3^{\text {rd }}$ ed. (Thomas Nelson Publication, 1897), https://www.biblestudytools.com/dictionary/covenant/accessed 2 February 2018.

${ }^{5}$ Cf. Jeremiah 34:18.
} 
ment word "Covenant" generally refers to a bond or an establishment of a treaty. However, we must note that Biblical scholars hold widely different views as to the number of the major covenants that did exist in the Bible.

One common type of covenant found in the Old Testament, notwithstanding the diverse opinions of Biblical scholars is the unconditional divine covenant wherein God alone undertakes obligation without any corresponding responsibility. An example of this type of covenant is God's covenant with Noah, ${ }^{6}$ David, ${ }^{7}$ and Abraham. ${ }^{8}$ Another type of covenant in the Old Testament is the Covenant of Obligation wherein the human parties swear to abide by God's laws. Mendenhall claims that the Israelite covenant resembles the early Near Eastern treaties in major emphases and intent. According to him: "God gives the covenant - as at Sinai (Ex. 20) or Shechem (Jos. 24) - based on his past gracious actions, but without himself swearing to any performance." ${ }^{9}$ On the contrary, Lothar Perlitt argues that the idea of a covenant formula is very artificial which was very popular among the Old Testament scholars in the 1960s. He insists that this formula was never complete in the Old Testament and that the constituent element like the commands, blessings and curses could be explained from the language and religion of the Israelites which is entirely different from the Near Eastern political instruments. ${ }^{10}$ Notwithstanding the differences in opinion, the point of emphasis is the bond and commitment that the concept of covenant teaches. From the time of the early Christians, the word covenant has been used in connection with the sacraments, especially the Eucharist. ${ }^{11}$ It is, therefore, no surprise that the writer of the letter to the Hebrews views Jesus Christ as the advocate of the new covenant who set up a new saving order of reconciliation by His self-giving.

The sacraments of Christian initiation are Baptism, Confirmation, and the Eucharist. These sacraments serve as the foundation for every Christian life. The Western Church recognizes seven rites starting from the time of Peter Lombard as sacraments in the strict sense. These seven sacraments were endorsed both by the Councils of Tent and the Vatican, and also adopted by the Eastern Orthodox Church. However, the Churches of the Reformation only accepted two of these

${ }^{6}$ Cf. Genesis 9:8-17.

${ }^{7}$ Cf. 2 Samuel 7.

${ }^{8}$ Cf. Genesis 15 \& 17.

9 George Mendenhall, Law and Covenant in Israel and the Ancient Near East, Pittsburgh, 1955); Delbert R. HILlERs, "Covenant," The Encyclopedia of Religion, 135.

${ }^{10}$ Cf. Lothar PerLitT, "Covenant," in: The Encyclopedia of Christianity, 710.

${ }^{11}$ Cf. Matthew 26:26-29; Mark 16:22-25; Luke 22:15-20; 1 Corinthians 11:23-25. 
sacraments: Baptism and the Eucharist as the only sacraments instituted by Christ. By derivation, the Greek word $\mu \nu \sigma \tau$ 亿 ment Greek is translated into Sacramentum in the Latin Vulgate Bible. It is from this translation that we derive our English word sacrament. ${ }^{12}$ In the work of Peter Lombard, Bishop of Paris 1159-1160, which was a major text in Western Christendom, Sacramentum in its general use as applied only strictly to Christian rites is defined as "quod ita signum est gratiae Dei et invisibilis gratiae forma ut ipsius imaginem great et causa existat - an outward and visible sign of an inward divine grace, which it both aptly represents and also actually imparts to the recipient."13 Thus, this definition suggests that behind the conception of a sacrament lies the notion of the "sacred" beyond the human world. The faithful are born anew through the sacrament of Baptism and strengthened by the sacrament of Confirmation; finally, they receive the food of eternal life in the Eucharist. ${ }^{14}$

\section{COVENANT AND THE HOLY BIBLE}

The Holy Bible is both doctrinal and historical. The Bible otherwise known as Scriptures is divided into two: Old Testament and New Testament. The word "testament" is translated from the Greek word diatheke. It represents "a fundamental feature of revelation, the Covenant or treaty which God made with a people whom he had chosen, the people of Israel." ${ }^{15}$ It contains God's revelation of himself and his relationship with his people. The Old and New Testaments are the stories of the history of our salvation, the divine plan of our redemption through God's Covenant with the Israelites sustained and continued by God himself irrespective of the people's unfaithfulness. The stories continued until the time of Christ who finally sealed God's relationship with his people and won salvation for humanity by his blood on the Cross of Calvary. The salvation

\footnotetext{
12 Cf. Giles Dimock, "Sacraments," Lectures, Franciscan University, Steubenville, Ohio, 2001, http://www.jesuschristsavior.net/Sacraments.html, accessed 3 March 2018.

${ }^{13}$ Peter Lombard, Sententiae, Book iv in: Clement Charles Julian WebB, "Sacrament," The Encyclopaedia Britannica, 4 ed., vol. 19 (London: The Encyclopaedia Britannica Company, Ltd, 1929), 796-7.

${ }^{14}$ Cf. Catechism of the Catholic Church, Revised ed. (Nairobi: Paulines Publications Africa, 2002), no. 1212, p. 281.

15 Wilfrid J. HARRInGton, Record of Revelation: The Bible (Chicago: The Priory Press, 2005), 3.
} 
story is about how each of us can enter into this Covenant and abide by it, to attain personal salvation. It is about what we should know about God and his people to become accepted by him. In the first place, the word of God which is the source of our faith is meant for us as it was for our remote ancestors in faith. "To reach man and transmit the message of salvation, this word became 'incarnate,' even as the Word of God became flesh to achieve man's salvation. God's word became 'the Book,' or rather 'the Books' of the Bible." ${ }^{\prime 6}$ It, therefore, means that the knowledge of the Bible is essential for Christians to be able to know more about God, their commitments with him and what they must do to achieve their salvation. The Bible nourishes Christians spiritually and informs them about the things of God. For this reason, parents, teachers and guidance of children to be baptized and already baptized are expected to have their Bible at home and also take time to read and teach their children the lessons from the Bible.

\section{COVENANT IN THE OLD AND NEW TESTAMENTS}

The Old Testament is the story of the Israelites in the light of their covenant with God. Their infidelity to God and the unfailing fidelity on the part of God characterize this story. For certain, the Israelites were punished on several occasions by God for their failure to live up to their responsibilities within the covenant. II Kings 17:7-8, for instance, speaks of the sins of the Kingdom of Israel up north as follows: "This disaster happened because the people of Israel had sinned against the Lord their God who had brought them out of the land of Egypt from the power of Pharaoh King of Egypt and because they had worshiped other gods. They had lived according to the customs of the nations that the Lord had dispossessed before the Israelites and the customs the kings of Israel had introduced." As a result of this sin, "God was very angry with Israel, and removed them from His sight [...] rejected all the descendants of Israel, afflicted them, and delivered them into the hand of plunders, until He had cast them from His sight."17

John Ritenbaugh explains that "God's punishment, though, is never an end in itself, nor does He punish in wild anger or frustration. Rather, He punishes in the best way and at the best time to bring individuals to repentance. He

\footnotetext{
${ }^{16}$ Roland DE VAUX, Foreword to Record of Revelation, v.

${ }^{17}$ II Kings 17:18-20.
} 
has not forgotten His promises to Abraham, Isaac, promises, and Jacob, but $\mathrm{He}$ will correct their descendants so that $\mathrm{He}$ can eventually save His people and give them the promises. The process will be painful but also effective; Israel will come to repentance (Romans 11:25-29)." 18 On the other hand, the New Testament reveals the fulfilment of God's plan - the redemption of humanity. Thus, "the coming of the Son of God naturally marked the beginning of a new era. God made a new and final treaty, sealed in the blood of Christ, with a new people - yet directly descended from the old - the Church." ${ }^{19}$ It must be understood that the old covenant, although distinct is closely linked to the new. In fact, the old covenant was a preparation for the new and can be fully understood only in the light of fulfilment. ${ }^{20}$ Strictly speaking, the word "new" as in "new covenant" does not mean brand new as in the case of never seen before but renewed. The Greek term "neos" means new in the sense of just arrived. The Greek term "kai-nay" also means something that has been renewed. Thus, "kainós" properly speaking means new in quality (innovation). So when Jesus talked about the New Covenant during the institution of the Eucharist, he was not implying a brand new commitment in that sense but rather a renewed covenant that started long ago down to the time of Abraham, Isaac, Jacob, Moses, and David.

\section{GOD'S COVENANT WITH HIS PEOPLE}

The Catechism of the Catholic Church teaches that our first parents, Adam and Eve, were not only created good but were in good friendship with God their Creator; in perfect harmony with themselves and the creation around them, and most importantly, were constituted in an original state of holiness and justice. ${ }^{21}$ By the grace of this original holiness, they were to share in the divine life. ${ }^{22}$ This state was only to be surpassed by the glory of the

\footnotetext{
18 John Ritenbaugh, "Leviticus 26:25," Forerunner Commentary: Bible Verses about Israel's Punishments, https://www.bibletools.org/index.cfm/fuseaction/About.website, accessed 30 January 2018.

${ }^{19}$ Wilfrid J. HARRINGTON, Record of Revelation, 4.

${ }^{20}$ Cf. Ibidem.

${ }^{21}$ Cf. Catechism of the Catholic Church, no. 375, pp. 104-105; LG. 2; The inner harmony of the human person, the harmony between man and woman, and finally the harmony between the first couple and all creation, comprised the state called "original justice."

${ }^{22}$ Cf. Ibidem.
} 
new creation in Christ, and as long as they remained in this state, they would not have to suffer or die. ${ }^{23}$ However, this original state of our first parents came to be lost by their sin of disobedience. ${ }^{24}$ The sin of disobedience brought upon humanity five consequences: (1) Loss of Righteousness, (2) Separation from God, (3) Cursed environment, (4) Physical death and suffering, and (5) Clothing. According to the Scriptures, after Adam and Eve disobeyed God, their "eyes were opened", and they became aware of their nakedness, trying to cover it up by sewing fig leaves together. ${ }^{25}$ This pitiable state of man lasted until the call of Abraham in Genesis 12 when God out of mercy began the move to reestablish man in a union of lasting friendship through covenant. The remarkable thing is that God in His omnipotence consents to enter into covenant with humanity that is feeble and sinful. God's covenant with man in the Old Testament, however, does not exclude other covenants between people who related to each other as equals. Evidence of this kind of covenant is the case of David and Jonathan in 1 Samuel 18:3 who entered into a covenant because of their love for each other. There is no doubt that this covenant between them came with certain responsibilities.

It must be remembered that centuries before the time of Abraham God made a covenant with Noah, and in this covenant, God assured Noah that never again would He destroy the world by flood. ${ }^{26}$ The rainbow serves as the sign of the covenant and the significant word used by God was remember (At the appearance of the rainbow God will recall his promise). ${ }^{27}$ In a bid to re-establish humanity in a lasting friendship, God decided to form a nation being founded in the descendants of Abraham. This is to say that God's covenant with Abraham established the basis for the birth of a nation known today as Israel. When Abraham was living in Haran, at the age of seventyfive (75), he received a call from God to leave the pagan territory of Haran to an unknown land that God would show him. God promised Abraham that He would make him and his descendants a great nation. ${ }^{28}$ As a man of faith, Abraham obeyed God without any doubt, and the Lord never ceased to reaffirm His promise to Abraham. ${ }^{29}$ "Look now toward heaven, and count

\footnotetext{
${ }^{23}$ Cf. Ibidem, 376; Genesis 2:17; 3:16, 19.

${ }^{24}$ Cf. Genesis 3:1-24.

${ }^{25}$ Cf. Genesis 3:7.

${ }^{26}$ Cf. Genesis 9:8-17.

${ }^{27}$ Cf. Ibidem.

${ }^{28}$ Cf. Genesis 12:1-3.

${ }^{29}$ Cf. Genesis 15 .
} 
the stars if you are able to number them." And the Lord said to him, "So shall your descendants be." 30 As a sign of the covenant, Abraham and his children were commanded by God to be circumcised. ${ }^{31}$ God repeated this covenant again to Isaac (Abraham's son) in Genesis 17:19 and subsequently to Jacob, down to the time of Moses: "I will establish my covenant between you and me, and your offspring after you throughout their generations, for an everlasting covenant, to be God to you and your offspring after you." 32

According to Exodus 2:24, after the Israelites had moved into Egypt during the time of Joseph, a new Pharaoh who knew not Joseph came upon the scene and turned them into slave workers. The children of Israel cried out to God, "So God heard their groaning and remembered His covenant with Abraham, with Isaac, and with Jacob." After a succession of ten plagues upon the land of Egypt, the Lord brought the Israelites out of the hands of Pharaoh with great power and with a mighty hand. ${ }^{33}$ After the Israelites left Egypt, they arrived at Mount Sinai where they established a covenant with God known as the Mosaic covenant. This covenant, however, was followed by the giving of the law. There in the presence of God, the Israelites promised to obey the demands of the covenant. Sacrifices were made to seal this covenant, and the blood of the sacrificial animals was poured on the altar and sprinkled on the people to symbolize the agreement of the commitment: "Behold the blood of the covenant which the Lord has made with you in accordance with all these words." "34 The covenant God established with the Israelites on Mount Sinai was the culmination of the exodus event and a confirmation of the covenant God made with Abraham, Isaac, and Jacob. The Mosaic covenant was followed by many other covenants till the time of David. David and his descendants were established as the royal heirs to the throne of the nation of Israel. ${ }^{35}$ Finally, this covenant agreement reached its fulfilment with the birth of Jesus, a descendant of the line of David.

\footnotetext{
${ }^{30} \mathrm{Cf}$. Genesis 15:5.

${ }^{31} \mathrm{Cf}$. Genesis 17:10-11.

${ }^{32}$ Genesis 17:7.

${ }^{33}$ Cf. Exodus 32:11.

${ }^{34}$ Exodus 24:8.

${ }^{35}$ Cf. 2 Samuel 7:12-13.
} 


\section{GOD'S COVENANT AND THE PASSOVER MEAL}

The Book of Exodus, chapter 12 focuses on the Passover meal that commemorates the exodus and salvation of the Israelites. Before roasting the lamb, the Israelites were ordered to sprinkle the blood of the lamb on the doorframes of their homes. The blood was a sign to the Lord that Israelites lived in that house, thus preventing the firstborn of that house from being struck dead when the Destroyer goes round striking down all the firstborn of the Egyptians. In this way the blood served as a protective, identifying mark of belonging to Israel. According to Steven Rodeheaver's explanation "Verses 14,17, and 24-26 make one thing clear: this meal is to be celebrated annually from generation to generation as a means of remembering Yahweh's salvation." ${ }^{36}$ He goes further to explain that "the meal teaches the event. Eating the meal every year would teach the event, engraving it deep within Israel's self-understanding and God-understanding. Eating the meal not only is a reminder of that last supper in Egypt, but it is a re-experiencing of that event." ${ }^{, 37}$

It must be recalled that Moses gave regulations regarding those to take part in the Passover meal. According to Moses, only those who are circumcised may participate; that is, only those who are members of the covenant with Abraham. The All Saints Knoxville document, Typology: The Sacraments of Initiation and the Baptism supports Rodeheaver that "the issue is not blood descent but covenant membership." 38 It follows, therefore, that strangers who are not of Abraham's descent have every right to join in the Passover meal provided they have joined the covenant people through the initiation of circumcision.

\section{THE NEW TESTAMENT AND THE SACRAMENTS OF INITIATION}

In so many passages of the New Testament, the Church is seen as the real Israel. ${ }^{39}$ In like manner, the initiation of Christian baptism has come to

\footnotetext{
${ }^{36}$ Steve RodehEAVER, "Exodus 12: The Meal that Teaches Salvation,” The Voice: Biblical and Theological Resources for Growing Christians, http://www.crivoice.org/biblestudy/exodus/ bbex17.html, accessed 28 January 2018.

${ }^{37}$ Ibidem.

38 Ibidem. Cf. All Saints KnoxviLle, Typology: The Sacraments of Initiation and the Baptism, https://allsaintsknoxville.org/documents/2018/1/typology.pdf, accessed 3 March 2018.

${ }^{39}$ Cf. Roman 9:6f; Galatians 3:6-7.
} 
replace the initiation of the Old Testament circumcision through which people become members of God's family and children of Abraham - the covenant people. This explains why the sacrament of baptism is seen as a door to God's family. As in the case of the initiation of circumcision, likewise, in the sacrament of baptism, the issue is not blood descent but covenant membership. Thus, the sacrament of baptism unites and binds its members more like brothers and sisters than their blood ties. This sacrament also cleanses us from the original sin we incurred from our first parents and at the same time symbolizes our new commitment or covenant with God through Jesus Christ. This explains why during the celebration of the sacrament of baptism, the candidates are called to renounce Satan and sin and to make a profession of faith. In summary, the sacrament of baptism stands as a symbol of our new commitment or covenant with God sealed by the blood of Christ.

Similarly, the Lord's Supper is our Passover. Jesus initiated the new covenant in the upper room on the evening before His arrest and crucifixion. ${ }^{40}$ The Lord's Supper is the meal that teaches the event of our salvation starting with the call of Abraham. This meal is to be partaking only by the covenant people (Baptized people), God's people adopted through Jesus Christ. The Eucharist reminds us of the Exodus story and the freedom that was won by the mighty power of God. It further reminds us of the birth, the sufferings and death of Jesus, his resurrection, and the promise of Christ's return. In this sacrament "the event of our salvation is brought forward into the present. The future of our salvation, the consummation of the Kingdom is brought backwards into the present. We are called to live true to both events in this in-between time. Like the Passover meal taught Israel, this meal teaches us who we are: a people saved by the mercy of God in Christ Jesus that we might declare His praises." 41 We are a people bound and sealed by the blood of Christ in a new covenant. This is why Christ constantly reminds us in the Eucharist that "This is the chalice of my blood, the blood of the new and everlasting covenant, which will be shared for you and for all for the forgiveness of sins, do this in memory of me." ${ }^{42}$

Furthermore, the role and understanding of the Holy Spirit is not a new knowledge in the New Testament. We must recall that the new covenant we

\footnotetext{
${ }^{40}$ Cf. Matthew 26:28.

${ }^{41}$ Steve RodehEAVER, "Exodus 12: The Meal that Teaches Salvation," The Voice: Biblical and Theological Resources for Growing Christians, http://www.crivoice.org/biblestudy/exodus/ bbex 17.html, accessed 28 January 2018.

${ }^{42}$ Matthew 26:26-28; Mark 14:22-24, Luke 22:17-20, 1 Corinthians 11:23-25.
} 
enjoy today through Jesus Christ was prophesied through the prophets of the old hundreds of years before Christ. Jeremiah, for example, spoke of this covenant. ${ }^{43}$ God, in the Book of Joel, says "I will pour out my Spirit on all people. Your sons and daughters will prophesy, your old men will dream dreams, your young men will see vision." 44 Also in the Book of Prophet Ezekiel, we find a similar promise: "A new heart also will I give you, and a new spirit will I put within you: and I will take the stony heart out of your flesh, and I will give you a heart of flesh. And I will put my Spirit within you, and cause you to walk in my statutes, and you shall keep my judgments, and do them. Moreover, I will make a covenant of peace with them: it shall be an everlasting covenant with them."45

The establishment of the New Covenant by Christ made the role of the Holy Spirit apparent and extremely necessary to continually remind the faithful of the blessings and commitments that are connected with the covenant. It means therefore that not only are we saved, redeemed and restored through Jesus' precious blood, but the Holy Spirit continually speaks these things to us so that we will have confidence in our relationship with God. ${ }^{46}$ In John 14: 26 Jesus says "But the Counselor, the Holy Spirit, whom the Father will send in my name, will teach you all things and will remind you of everything I have said to you." In the sacrament of Confirmation, God in Christ gives his spirit to the confirmed, and the gift of the Holy Spirit is fundamental to the Christian service. ${ }^{47}$ The New Testament spells out the work of the Spirit as being essential for the renewal and awakening of the Christian life.

\section{THE SACRAMENTS OF INITIATION: BAPTISM, CONFIRMATION AND EUCHARIST}

The norm, as set down in the new Rite of Christian Initiation is that a person should receive all three sacraments - Baptism, Confirmation, and Eucharist - during the annual celebration of the Easter vigil, following

\footnotetext{
43 Jeremiah 31:31-34.

44 Joel 2:28.

${ }^{45}$ Ezekiel 36:26-27; 37:26.

${ }^{46}$ Cf. Hebrews 10:22.

47 Cf. Leon Morris, New Testament Theology (Grand Rapids, Michigan: Zondervan, 1990), 194.
} 
a suitable period of the formation known as Catechumenate. ${ }^{48}$ These sacraments of Christian initiation free both men and women from the power of darkness, and at the same time, enable them to receive the Spirit of adoption which makes them sons and daughters of God. ${ }^{49}$ Baptism incorporates men and women into Christ. They not only receive forgiveness for all their sins but also are raised from their natural human state to the dignity of adopted children of God. Through water and the Holy Spirit, they become new creatures and adopted children of God. ${ }^{50}$ In Confirmation, men and women are signed with the gift of the Holy Spirit which enables them to be more perfectly the image of their Lord. As soldiers of Christ, they bear witness to the Lord before the world and readily work for the growth of the Church. Finally, in the Eucharist, they eat the flesh and drink the blood of Christ so that they may have eternal life. In this Eucharistic sacrifice, the priest offers the entire community of the faithful to God, and together they pray for a greater outpouring of the Holy Spirit for the unity of the entire human race. ${ }^{51}$

The Rite further states that Baptism, Confirmation and the Eucharist are all given to the new convert at the same time. Even small infants were simultaneously baptized, confirmed and given communion. If children were too small to receive the consecrated bread, a small drop of the consecrated wine was dabbed on their lips. This remains the practice in the Eastern Churches till date. ${ }^{52}$ Today, in the Latin Church, i.e. the Roman Catholic Church, adult converts are still baptized and confirmed and receive the Eucharist at the same time especially since the restoration of the Rite of Christian Initiation of Adult in 1973. But infants are baptized a few days or weeks after birth, receive the Eucharist when they are seven years and above and are confirmed some years later.

The Sacraments of Christian initiation came to be separated in the course of the Church's history in the Roman Rite. The separation of the three sacraments has a history behind it. As the early Church was very much city based, it was easy for the Bishop to be present at every baptism to administer the full rites of initiation which included Baptism, Confirmation and the Eucharist. But when the Church grew larger and expanded into rural parishes, it became much more challenging for the Bishop to be present to celebrate

\footnotetext{
${ }^{48}$ Cf. The Rites of the Catholic Church (New York: Pueblo Publishing co., 1976), 3-4.

${ }^{49} \mathrm{Cf}$. Ibidem.

${ }^{50} \mathrm{Cf}$. Ibidem.

${ }^{51} \mathrm{Cf}$. Ibidem.

${ }^{52} \mathrm{Cf}$. The Rites of the Catholic Church, Introduction.
} 
these sacraments at every ceremony. Because the Church wanted to preserve the tradition of having the Bishop as the minister of Confirmation, the rite became separated from Baptism, and the local priest could then administer the Eucharist. Once the separation had taken place, it became a good practice that children should wait until they were old enough to have a fuller understanding of what was happening before they receive the sacrament of Confirmation. Although the Church has separated the rites of these sacraments, properly speaking, together, they remain one single rite of Christian initiation.

For some scholars, Confirmation completes the baptismal rite. According to them, this is not to devalue the rite of baptism in any way, but it does simply mean that the Christian initiation remains incomplete. ${ }^{53} \mathrm{We}$ find similar teaching in the catechism text. According to this text:

From that time on the apostles, in fulfilment of Christ's will, imparted to the newly baptized by the laying on of hands the gift of the Spirit that completes the grace of Baptism. For this reason, in the Letter to the Hebrews, the doctrine concerning Baptism and the laying on of hands is listed among the first elements of Christian instruction. The imposition of hands is rightly recognized by the Catholic tradition as the origin of the sacrament of Confirmation, which in a certain way perpetuates the grace of Pentecost in the Church. ${ }^{54}$

The Catechism maintains that the sacrament of Confirmation is our own Pentecost. It means therefore that when we are confirmed the Holy Spirit is poured out on us. This explains the words of the Bishop during confirmation. During the celebration of this rite, the Bishop places his hands on the candidates' heads and then anoints their foreheads with the oil of chrism saying the words: Be sealed with the Gift of the Holy Spirit. ${ }^{55}$

In the meantime, some other scholars have argued that there is no separate rite of Confirmation in the New Testament. Where the Spirit is given, the Spirit is given in connection with Baptism. ${ }^{56}$ Also where the Spirit is manifested in connection with the imposition of hands, it always concerns Baptism. ${ }^{57}$ They maintain that the prerogative of the bishops as ministers of the

\footnotetext{
${ }^{53}$ Cf. Mares WALter, Faith for the Future: An Illustrated Catechism of Catholic belief in words and pictures (Hampshire: Redemptorist Publications, 1997), 89-90.

${ }^{54}$ Catechism of the Catholic Church, no. 1288, p. 329.

55 Ibidem.

${ }^{56}$ Cf. Acts. 8:14-18; 9:31.

${ }^{57}$ Cf. Acts. 2:41; 9:17-19; 19:1-7; R.P. MCBRIEN, Catholicism (New York: Harper Collins Publishers, 1966), 816-817.
} 
post-baptismal rites in the West did not presuppose, but in fact, created two independent sacraments. It was only in the high Middle Ages that a specific theology of Confirmation was developed to justify the autonomous rite carried out only by the bishops. It was from this background that the notion emerged that Confirmation provides a gratia ad robur (grace for strength), the power to witness, and the armour of the soldier of Christ. ${ }^{58} \mathrm{We}$ can, therefore, say that the sacramental grace and the ecclesial effect of the sacrament of Confirmation give the recipient the strength and the character to bear witness to Christ.

Sacraments are signs that point to the forgiveness and mercy of God and the goal of the Covenant is the revelation of love. The plan of God to save us from sin and death is revealed in the sacraments which bring us into fellowship with each other. They offer us healing and forgiveness, joining us with each other in love and service. Sacraments are signs of God's love, but they are also more than just signs. St. Augustine gave us the first technical definition of a sacrament as a sign of grace, "a visible sign of invisible grace." St. Thomas Aquinas added the notion of the efficacious sign of grace, that is, the sacraments cause what they signify. A sacrament is not just an ordinary sign, but the sign of salvation which accomplishes the very salvation that it signifies. It is for this reason that the Church calls the sacraments efficacious signs. An efficacious sign is "a sign which has an effect." ${ }^{59}$ In the celebration of every sacrament, it is Jesus Christ who makes the first move in coming to lift up the person in need of salvation, just as he came to lift up his friend Lazarus in the village of Bethany. ${ }^{60}$

\section{CONCLUSION}

In conclusion, living and loving the truth of God is the responsibility of those who are bound to God in a covenant, whether the Old or the New Covenant. This is our side of the deal which should be kept knowing that God's actions are always motivated by his love. Our covenant with God places God at the centre of our lives and at the same time places us at the service of God. Like St Paul, we must believe that God is the only living and

\footnotetext{
${ }^{58}$ Cf. R.P. MCBrien, Catholicism, 816-817.

${ }^{59}$ Ibidem.

${ }^{60}$ Cf. Redemptorist Publications, 85-6.
} 
righteous One who enters into a fellowship with us and forms a family of his people here on earth. Being faithful to the demands of the covenant will bring down to us the benefits that flow with God keeping his. We must remember that Jesus' atoning death and resurrection were all signs of God's love, bringing us salvation. The salvation of the world on its part consists in its faithfulness to God, and this faithfulness brings upon the people of God abundant blessings and blessedness in his kingdom. ${ }^{61}$ Our faithfulness attracts God's mercy and separates us from evil. It gives us the fortitude in times of trouble. Psalm 112:1,2 among other things tells us that "Blessed is the man who fears the Lord, who greatly delights in His commands. He will not fear when the evil day comes. Because his heart is steadfast, trusting in the Lord." Other benefits include good health, ${ }^{62}$ prosperity, ${ }^{63}$ children, ${ }^{64}$ and security. ${ }^{65}$ On the contrary, it must be remembered that God is not passive to $\sin$.

\section{REFERENCES}

All Saints Knoxville. Typology: The Sacraments of Initiation and the Baptism, https://allsaintsknoxville.org/documents/2018/1/typology.pdf, accessed 3 March 2018.

Catechism of the Catholic Church. Revised ed. Nairobi: Paulines Publications Africa, 2002.

DIMOCK, Giles. "Sacraments," Lectures, Franciscan University, Steubenville, Ohio, 2001, http: //www.jesuschristsavior.net/Sacraments.html, accessed 3 March 2018.

Easton, M.G. „Covenant.” In: Illustrated Bible Dictionary, $3^{\text {rd }}$ ed. Thomas Nelson Publication, 1897, https://www.biblestudytools.com/dictionary/covenant/accessed 2 February 2018.

Harrington, Wilfrid J. Record of Revelation: The Bible. Chicago: The Priory Press, 2005.

HILlers, Delbert R. "Covenant." In: The Encyclopedia of Religion. Vol. 4. Ed. by Mircea Eliade. New York: Macmillan Publishing Company, 1987.

Lombard, Peter. Sententiae, Book IV. Cited after: Clement Charles Julian WebB. In: "Sacrament," The Encyclopaedia Britannica. 4 ed. Vol. 19. London: The Encyclopaedia Britannica Company, Ltd, 1929.

Mendenhall, George. Law and Covenant in Israel and the Ancient Near East. Pittsburgh, 1955. Cited after: Delbert R. HILlERs, “Covenant.” The Encyclopedia of Religion. Vol. 4. Ed. by Mircea Eliade. New York: Macmillan Publishing Company, 1987.

MCBRIEN, R.P. Catholicism. New York: Harper Collins Publishers, 1966.

MorRIS, Leon. New Testament Theology. Grand Rapids, Michigan: Zondervan, 1990.

\footnotetext{
${ }^{61}$ Cf. John 17:1-3; Romans 6:23.

${ }^{62}$ Cf. Exodus 15:26.

${ }^{63}$ Cf. Malachi 3:8-12.

${ }^{64}$ Cf. Psalm 127:3-5.

${ }^{65}$ Cf. Psalm 46.
} 
PerlitT, Lothar. "Covenant." In: Erwin FAHLBusch et al. (eds.). The Encyclopedia of Christianity. Vol. 1, Michigan: Wm. B. Eerdmans Publishing Company, 1999.

RitenBAugh, John. "Leviticus 26:25." Forerunner Commentary: Bible Verses about Israel's Punishments, https://www.bibletools.org/index.cfm/fuseaction/About.website, accessed 30 January 2018.

RodeheAver, Steve. "Exodus 12: The Meal that Teaches Salvation." The Voice: Biblical and Theological Resources for Growing Christians, http://www.crivoice.org/biblestudy/exodus/ bbex17.html, accessed 28 January 2018.

The Rites of the Catholic Church. New York: Pueblo Publishing co., 1976.

WALTER, Mares. Faith for the Future: An Illustrated Catechism of Catholic belief in words and pictures. Hampshire: Redemptorist Publications, 1997.

\section{PRZYMIERZE BOŻE I SAKRAMENTY CHRZEŚCIJAŃSKIEJ INICJACJI}

\section{S t r e s z c z e n i e}

Katechetyczne wyjaśnienie Pisma Świętego i jego związku z liturgią stało się pilne, szczególnie w dzisiejszym świeckim społeczeństwie, w którym większość doktryn i praktyk religijnych Kościoła jest zagrożonych utratą znaczenia lub niewłaściwą interpretacją. Twierdzono również, że istnieje związek między przymierzami Boga a sakramentami inicjacji chrześcijańskiej w Nowym Testamencie. Artykuł ma na celu ukazanie biblijnej relacji sakramentów wtajemniczenia chrześcijańskiego z przymierzami Boga. Badanie to prowadzi nie tylko do wyjaśnienia ze względu na rosnącą świadomość i ciągłe pogłębianie rozumienia, ale także potwierdzenie znaczenia tych sakramentów i zasadniczej natury Chrystusa, który jest mądrością i mocą Boga.

Słowa kluczowe: przymierza Boga; sakramenty inicjacji chrześcijańskiej; Chrystus - mądrość i moc Boga. 